\title{
Glassy cell carcinoma of the cervix uteri
}

INSERM

\section{Source}

INSERM. (1999). Orphanet: an online rare disease and orphan drug data base. Glassy cell carcinoma of the cervix uteri. ORPHA:213833

Glassy cell carcinoma of the cervix uteri is a rare cancer of the uterine cervix, composed of nests of large neoplastic cells with "ground glass" cytoplasm, surrounded by a stroma with prominent eosinophilic infiltrates. It is a poorly differentiated, aggressive variant of adenosquamous carcinoma that usually affects young women and presents with dysfunctional vaginal bleeding and lower abdominal pain. Distant metastases to the lungs, liver spleen or bones are often present at the time of diagnosis. It is often associated with high-risk HPV-infection (types 18, 16 and 32). 